\title{
Speaking Sub-Skills Exercise and Its Teaching Techniques: Document Analysis of Arabic Textbooks
}

\author{
N. Farisha M. Khaizal, M. Khalid M. Nasir*, Nik Mohd Rahimi, Fatimah A-Rahman \\ Universiti Kebangsaan Malaysia (UKM), Bangi, Malaysia \\ Email: nfarisha@gmail.com, ^mdkhalid@ukm.edu.my, nik@ukm.edu.my, cttieylid@gmail.com
}

How to cite this paper: Khaizal, N. F. M., Nasir, M. K. M., Rahimi, N. M., \& A-Rahman, F. (2021). Speaking Sub-Skills Exercise and Its Teaching Techniques: Document Analysis of Arabic Textbooks. Creative Education, 12, 2159-2166. https://doi.org/10.4236/ce.2021.129165

Received: August 19, 2021

Accepted: September 23, 2021

Published: September 26, 2021

Copyright $\odot 2021$ by author(s) and Scientific Research Publishing Inc. This work is licensed under the Creative Commons Attribution International License (CC BY 4.0).

http://creativecommons.org/licenses/by/4.0/

\begin{abstract}
Preparation of quality textbooks could contribute to more efficient teaching and learning processes, especially from the aspects of speaking skill. The purpose of this study is to analyze the instructions and teaching techniques in speaking skill as a reinforcement exercise in enhancing the mastery of Arabic language to students. This study employed qualitative approach through a case study in the form of exploration of sub-skills instructions based on the Arabic textbooks. Structured interview methods in the form of group discussion with three Arabic teachers were used to identify the techniques used in teaching Arabic speaking skill. The analysis identified four main themes in spoken subskills covering aspects of pronunciation, fluency, speaking in the form of discourse and spontaneously speaking. The findings of the second review feature five speaking skill teaching techniques namely Takrir Techniques (Repetition), Tadwir Techniques (Rotation), Language Games Techniques, Lecture Techniques and Greeting Techniques. Thus, the findings of this study can be used as a guidance for teachers to improve enhance their teaching technique especially in Arabic speaking skills, towards their students, based on the language sub-language instructions in the textbook.
\end{abstract}

\section{Keywords}

Speaking Skills, Teaching Technique, Arabic Language, Presence, Community

\section{Introduction}

Textbooks are the main references to access information and knowledge about syllabus and learning content for teachers and students. In line with the objectives of The Secondary School Standard Curriculum (KSSM) Arabic Form 1, the 
Ministry of Education (KPM) emphasizes language skills including speaking skills, towards the students in ensuring social interactions and applications can be implemented with effective value by them (Ministry of Education Malaysia, 2015). If the teacher has lack of understanding in teaching techniques based on exercise in the textbook, the students' mastery in speaking skills will be weak and this will affect the level of students' achievement in Arabic language learning (Hussin \& Ismail, 2021). Therefore, the suitability of teaching techniques to improve Arabic speaking skills should be taken into account by teachers to ensure that this additional language teaching is more effective (Ghani \& Sulaiman, 2019; Baharudin et al., 2018; Azmee et al., 2021; Radzi et al., 2021).

Due to issues aforementioned, this study aims to analyze the instructions of speaking sub-skills as a reinforcement exercise as well as appropriate speaking skills teaching techniques to enhance the mastery of Arabic language to students. Hence, researchers aim to highlight some themes for sub-skills based on reinforcement exercises in Form 1 Arabic textbooks as well as to identify the teaching techniques applied by Arabic teachers to make the teaching process to be more effective.

\section{Literature Review}

The KSSM replace the old curriculum is to reinforce the students listening, speaking, reading and writing skills, in order to enhance their ability to access knowledge and social interaction (Ministry of Education Malaysia, 2015). The contents of textbooks are set accordingly to the syllabus by the Ministry at each level of study. Most of the content and exercise provided in textbooks and exercise include four language skills i.e., reading skills, speaking skills, writing skills and listening skills (Zaiturrahmi \& Zulfikar, 2017).

The purposes of textbooks are also supported in the study of Hussin et al. (2016), who noted that the content of the textbooks should also be enriched with critical vocabulary and thinking skills to impede students to master language skills. Laabidi and Nfissi (2016) also proved that some of the criteria that need to be available to a good textbook must contain the syllabus and objectives of learning, relevant titles and equipped with various exercise and activities that are able to stimulate the minds of the students. Furthermore, each instruction in exercise in the textbook includes sub-speaking skills that teachers and students need to know. In the concept of education, the language sub skills carry the ability of students to master the key basics in the language skills to help them learn a good language (Katawazai et al., 2019). Hence, it can make it easier for teachers to use techniques that are compatible with the instructions for the sub-skills contained in the textbook especially speaking skill techniques.

Al-Sobhi and Preece (2018) conducted a study on four Arabic teachers and four secondary school students at Saudi School in Kuala Lumpur. Their findings show that the method of non-communicative teachers still use traditional methods and cause language learning to be ineffective. However, student language 
proficiency can be improved through diverse teaching techniques and activities especially in terms of language productive skills that include speaking and writing skills (Sahrir \& Muhammad, 2019). It refers to the ability of a student in using a language, which is the communication aspect which it is important to be mastered by every teacher and student so that the process of delivery of knowledge becomes easier especially in mastering the language skills (Zuki, 2017; Hasram et al., 2021; Hasram et al., 2020). In the Wekke's (2015) book assembled language teaching theories, the importance of language learning and the Arabic language teaching method that was often used since its inception, especially collaborative activities that do not directly improve language skills to students.

Among the teaching techniques of speaking skills which are initiated with pronunciation activities, Nokman et al. (2017) found that university students were still committing an error from the aspect of Arabic pronunciation due to the influence of dialect and spoken habits in the native language. Therefore, the problem of letters and words should be addressed from the beginning of learning so that it becomes immersed within the students as a good mastery in the native language. Thus, vocabulary repetition techniques traditionally in the teaching of Arabic language to students is essential (Aman \& Baharudin, 2019) with the presence of teachers, students and materials (Baharudin et al., 2018; Nasir, 2020; Nasir et al., 2018).

Therefore, the method of communicating informally, can train students to speak spontaneously as well as enhancing new vocabulary, especially non-native speakers. Indirectly, students will listen and understand every word and text carefully in order to speak more smoothly either in the form of phrases, the entire verse or the text of the discourse. Therefore, Jasni et al. (2020) study using the Arabic language literature method proves that practical and creative teaching techniques can attract students to learn Arabic in an active and fun atmosphere. In addition, the use of proposed model of teaching and learning of Arabic language learning in action studies carried out by Jamali et al. (2017) have featured some teaching skills teaching techniques have been used by teachers through communicative methods. They found most students agree that teachers carry out acting activities by applying techniques to provide spontaneous opportunities and exercise without seeing text based on the situation given. Through speech or lecturing techniques can also train students to communicate by expressing their arguments and opinions on something so that language skills, especially speaking skills can be mastered (Madun \& Mosin, 2020).

\section{Methodology}

This study employed a qualitative approach through an exploration case study based on the method of analyzing documents and interviews. The method of analysis of the document is conducted to examine the instructions of the speech sub-skills in the Arabic textbook of Form 1 KSSM. Meanwhile, interview methods are implemented to identify the teaching techniques used by Arabic teach- 
ers in teaching Arabic speaking skills. They were selected due to the expertise in teaching Arabic for more than 20 years. The instrument used in this study is document analysis (Bowen, 2009) and thematic analysis (Fereday \& Muir-Cochrane, 2006) and interviews (Hamzah, 2004). The first instrument used was the KSSM Form 1 Arabic textbook as the main document for analysis; to identify the instructions of sub-language skills in the textbook. The list of sub-language skills from the book of the Ministry of Education Ministry titled "Malay Language Teaching and Learning Syllabus Primary One to Six" of Ministry of Education Singapore (2015) was adapted to theme the classification on the sub-skill instructions.

The specific validity method of textbooks; by using the official documents used at school and focused on the contents of the sub-skill instruction items. Two experts who have extensive experience in the field of Arabic education were chosen to review and assess of contents for each sub language skills analysis. Based on the calculation made, with the expert's approval, the researcher obtained the Cohen Kappa coefficient index was 0.83 scale which indicated very good level. Then, interview questions are constructed on the main theme of sub-skills speaking after analyzing the document. The pilot study was conducted to ensure that the constructed questions are comprehensible and suit the level of understanding for the respondents.

Subsequently, structured interviews were conducted to obtain information on the teaching method of speaking skills from three Arabic teachers from two schools in one district in Negeri Sembilan. Interview items are adapted from the interview form conducted by Mahmood (2012) to identify the teaching technique of Arabic speaking skills. The interview session was conducted via phone calls with an average of eight minutes per teacher and all conversations were recorded using the call recorder application and notes were taking concurrently. Audio recording transcribed were then analyzed.

\section{Findings}

In term of sub-speaking skills, the findings of this document analysis were based on four main themes. First theme "Mention and sorting words with correct phrases" show that the least dominant instructions repeated in this speaking skill are explaining the relevant and clear information of the right aspects of words, phrases, and sentences spontaneously. Second theme "Speak fluently with proper intonation" indicate the second largest speaking sub-skill repeated by using the correct words, phrases and sentences. Each instruction given is a question directly where the student needs to look to the picture and call the word, phrase or sentence correctly. Third theme "Give insights with interesting ideas in simple or complex sentences" mentions and sorting words and sentences without seeing the text has less repeated. These instructions involve acting activities to train students to mention well and provide appropriate instructions based on the answers provided. Fourth theme "Describe relevant and detailed information spon- 
taneously" show the most dominant instructions repeated in these speaking skills are explaining the relevant and clear information of the right aspects of words, phrases and sentences spontaneously. More questions are directed to personalize or describe someone who is around students like parents, siblings, friends and teachers.

In term of technique of teaching speaking skill, the interview results show that the three teachers utilize textbooks during the teaching and learning session, especially the skills exercises in the textbook as a consolidation activity. In order to achieve learning objectives and reinforce the students' mastery of speaking skills, there are several teaching techniques that they have applied based on the theme of the sub-skill of the Speech for instance, 1) Mention and sorting words with correct phrase, Takrir Technique (Repetition), 2) Speak fluently with proper intonation, a) Tadwir Technique (Rotation), 3) Language games technique, 4) Give insights with interesting ideas in simple or complex sentences, Lecture techniques, 5) Describe relevant and detailed information spontaneously, Greeting techniques. In short, various techniques have been used by Arabic teachers to train students from aspects of pronunciation, accuracy, and the fluency in speaking, in the form of discourse texts and can speak spontaneously. Each technique has different ways and approaches but has the same goal of mastering Arabic language skills, especially on speaking skills. The three respondents also give their views that are almost identical because these techniques are often used in the teaching process of speaking skills.

\section{Conclusion}

The teaching technique of speaking skills is more easily delivered by teachers with the existence of details on the main theme classification for these sub-skills based on exercises in the textbooks. It is clearly noted that Arabic teachers often use takrir techniques (repetitions) for speaking activities and organizing words and phrases without seeing the text. This technique is a traditional method and is very concerned with the good vocabulary mastery so that students have acquired it. This is because the repetition of pronunciation or reading done by the students will enable them to understand the information (Aman \& Baharudin, 2019). It seems like an exercise activity that involves the list of listening, viewing, evaluating and understanding every meaning of the words or verses mentioned (Chin \& Yusoff, 2017). Therefore, the use of proper strategies and continuous exercise can help students master the method to be well-understandable with the precise and clear words (Din \& Seman, 2019). In line with Baharudin (2017), pronunciation is a key element that teachers need to ensure in learning Arabic language.

The implementation of the next teaching technique is a tadwir technique (rotation) and language game techniques focusing on the fluency of Arabic language speech. This technique adopts elements of movement and speech involving entertainment activities as well as more enjoyable or more fun language arts 
during the teaching and learning process (Febrian et al., 2017; Aman, \& Baharudin, 2019). The theme for the speaking sub-skills is aligned with the objective that has been drafted DSKP for the Arabic language where students are able to speak in various contexts of the aspect of word use, the word of the word, the use of complex sentences correctly. Students will also train to give opinions, critical views, and preparation of thoughtful ideas to further enhance the mastery of speaking until they have the confidence to speak in public (Madun \& Mosin, 2020).

In conclusion, this study has shown that the importance of knowledge on the speaking sub-skills to teachers so that the teaching process becomes smoother and effective especially the exercise contained in the textbook. The results of the textbook analysis can train students to understand the requirements of the questions so that they are able to complete the assignment well. The findings guide teachers to determine the techniques or methods of teaching that are appropriate to the sub-skills. However, this study is limited to exercise for speaking skills in Form 1 textbooks only. The future study is recommended to be conducted for speaking skills on Arabic textbooks in the upper secondary level, particularly using the Arabic-religious Curriculum known as Dini or Azhari Curriculum textbooks.

\section{Acknowledgements}

The researchers would like to thank Ts. Dr. M. Khalid M. Nasir and Prof. Dr. Nik Mohd Rahimi as well as the Faculty of Education, UKM for the opportunity to write this paper. The researchers would also like to express their gratitude to their family members.

\section{Conflicts of Interest}

The authors declare no conflicts of interest regarding the publication of this paper.

\section{References}

Al-Sobhi, S. B. M., \& Preece, A. S. (2018). Teaching English Speaking Skills to the Arab Students in the Saudi School in Kuala Lumpur: Problems and Solutions. International Journal of Education and Literacy Studies, 6, 1-11. https://doi.org/10.7575/aiac.ijels.v.6n.1p.1

Aman, A. A., \& Baharudin, H. (2019). The Pedagogy Practices among the Arabic Language Main Trainers in Teaching Vocabulary at the National School Level in Malacca. Global Journal al Thaqafah (GJAT), Special Issue (May), 15-27.

Azmee, F. A. N., Baharudin, H., \& Nasir, M. K. M. (2021). Strategi Pelaksanaan Elemen PAK21 Dalam Pdpc Nahu Bahasa Arab [Implementation Strategy of the 21st-Century Learning Elements in the Teaching and Facilitation of the Arabic Grammar]. International Journal of Advanced Research in Islamic Studies and Education, 1. http://myedujournal.com/index.php/arise/article/view/53

Baharudin, H. (2017). The Speaking Skills Strategies in Language Learning. Pelita Bahasa, 
17-19.

Baharudin, H., Nasir, M. K. M., Yusoff, N. M. R. N., \& Surat, S. (2018). Assessing Students' Course Satisfaction with Online Arabic Language Hybrid Course. Advanced Science Letters, 24, 350-352. https://doi.org/10.1166/asl.2018.12005

Bowen, G. A. (2009). Document Analysis as a Qualitative Research Method. Qualitative Research Journal, 9, 27-40. https://doi.org/10.3316/QRJ0902027

Chin, R., \& Yusoff, N. (2017). The Use of Language Learning Strategies in Mastering Reading Skills among the Special Need Students. Proceedings of the International Conference on the Scholarship of Teaching and Learning 2017. https://www.academia.edu/35752693/Proceedings ICSOTL

Din, A. F. M., \& Seman, M. (2019). Improving Arabic Language Speaking Skills through Utterance Mastering Strategy (UMS); Segmental and Suprasegmental. INSANIAH: Online Journal of Language, Communication, and Humanities, 2, 85-99.

Febrian, D., Lubis, M. A., Yasim, I. M., \& Wahab, N. S. (2017). Interactive Arabic Language Teaching Technique in Selangor Arabic Language Centre. ASEAN Comparative Education Research Journal on Islam and Civilization (ACER-J), 1, 78-93.

Fereday, J., \& Muir-Cochrane, E. (2006). Demonstrating Rigor Using Thematic Analysis: A Hybrid Approach of Inductive and Deductive Coding and Theme Development. International Journal of Qualitative Methods, 5, 80-92. https://doi.org/10.1177/160940690600500107

Ghani, K. A., \& Sulaiman, S. N. (2019). The Teaching of Speaking Skills in Arabic Language among The National School J-Qaf Teachers. The Online Journal of Islamic Education, 7, 1-14.

Hamzah, A. (2004). Qualitative Method in Sociocultural Research. Malaysian Journal of Media Studies, 6, 1-10.

Hasram, S., Arif, F., Nasir, M., Mohamad, M., Daud, M., Rahman, M., \& Mohammad, W. (2020). Online Games for Primary School Vocabulary Teaching and Learning: A Literature Review. Creative Education, 11, 2327-2336.

https://doi.org/10.4236/ce.2020.1111170

Hasram, S., Nasir, M. K. M., Mohamad, M., Daud, M. Y., Rahman, M. J. A., \& Mohammad, W. M. R. W. (2021). The Effects of WordWall Online Games (WOW) on English Language Vocabulary Learning among Year 5 Pupils. Theory and Practice in Language Studies, 11, 1059-1066. https://doi.org/10.17507/tpls.1109.11

Hussin, M., \& Ismail, Z. (2021). Grammatical Error Analysis in Arabic Language Textbook LASR KSSM. e-Proceedings of International Conference on Language, Education, Humanities \& Social Sciences (i-LEdHs2021), Machang, 22 February 2021, 445-455.

Hussin, N. I. S. M., Nimehchisalem, V., Kalajahi, S. A. R., \& Yunus, N. (2016). Evaluating the Presentation of New Vocabulary Items in Malaysian form Three English Language Textbook. Malaysian Journal of Languages and Linguistics (MJLL), 5, 60-78. https://doi.org/10.24200/mjll.vol5iss1pp60-78

Jamali, H. N., Abdul Rahman, A., Ku Azizan, K. F., \& Md Isa, S. N. (2017). Maintaining the Level of Arabic Language Basic Skills through Action Research. Sultan Alauddin Sulaiman Shah Journal, Special Issue, 29-43.

Jasni, S. R., Zailani Ahmad, S., \& Zainal, H. (2020). The Impact of Creative Approach in Teaching and Learning of Arabic Vocabulary. BITARA International Journal of Civilizational Studies and Human Sciences, 3, 10-21.

Katawazai, R., Haidari, M., \& Sandaran, S. C. (2019). An Evaluation of Sub-Skills (Vocabulary, Grammar and Pronunciation) in the Grade 9 English Textbook of Afghan Sec- 
ondary Schools. International Journal of Engineering and Advanced Technology, 8, 1236-1241. https://doi.org/10.35940/ijeat.E1176.0585C19

Laabidi, H., \& Nfissi, A. (2016). Fundamental Criteria for Effective Textbook Evaluation. EFL Journal, 1, 141-159. https://doi.org/10.21462/eflj.v1i2.13

Madun, M. F., \& Mosin, M. (2020). The Need of Public Speaking Course in Primary School Module: A Common Survey. Malaysian Journal of Social Sciences and Humanities (MJSSH), 5, 201-206. https://doi.org/10.47405/mjssh.v5i12.574

Mahmood, N. (2012). The Use of Arabic Language Teaching Method among Primary School Teachers: An Assessment. Thesis PhD, University of Malaya. http://studentsrepo.um.edu.my/5650/3/3. Lampiran Tesis Normazidah.pdf

Ministry of Education Malaysia (2015). Arabic Language Secondary School Standard Curriculum: Form 1 Assessment and Curriculum Standard Document. Malaysia's Ministry of Education (MOE).

Nasir, M. K. M. (2020). The Influence of Social Presence on Students' Satisfaction toward Online Course. Open Praxis, 12, 485-493. https://doi.org/10.5944/openpraxis.12.4.1141

Nasir., M. K. M., Mansor, A. Z., \& Rahman, M. J. A. (2018). Measuring Malaysian Online University Student Social Presence in Online Course Offered. Journal of Advanced Research in Dynamical and Control Systems, 10, 1442-1446.

Nokman, A. Z., Che Mat, A., Abu Bakar, A. F., Musilehat, N. S., \& Yaakub, A. N. (2017). Kesilapan Sebutan Bahasa Arab dalam Kalangan Bukan Penutur Jati. e-Academia Journal, 6, 100-108.

Radzi, N. I. A., Baharudin, H., \& Nasir, M. K. M. (2021). Strategi Kemahiran Komunikasi Dalam Pengajaran Bahasa Arab [Communication Skills Strategies in Arabic Language Teaching]. International Journal of Advanced Research in Islamic Studies and Education, 1. http://myedujournal.com/index.php/arise/article/view/55

Sahrir, M. S., \& Muhammad, I. S. (2019). A Survey of Students' Response Towards Arabic Language Teaching as a Second Language Master Academic Program in the International Islamic University of Malaysia (IIUM). Sultan Alauddin Sulaiman Shah Journal, 6, 248-262.

Singapore's Ministry of Education (2015). Malay Language Teaching and Learning Syllabus Primary One to Six: Implementation Starting with 2015 Primary One Cohort. Ministry of Education.

Wekke, I. S. (2015). Arabic Language Learning Model. Deepublish.

Zaiturrahmi, K. U., \& Zulfikar, T. (2017). Analysis of Instructional Questions in an English Textbook for Senior High Schools. English Education Journal (EEJ), 8, 536-552.

Zuki, K. N. M. (2017). The Acceptance of Malay Language as the Second Language among Bajau Students. International Journal of Humanities and Social Science Invention, 6, 1-11. 